\title{
Pro Bono: What's in it for law students?
}

Rather like the sentiment that Atticus Finch imparts on his young daughter; "You never really know a man until you've walked in his shoes," a law student can never know what it is like to work for a client until they have done so. Before they have interviewed a client, taken legal jargon and created understandable prose from it and before they have appreciated that a client's expectations and the realistic remit of the law can often be polar opposites they cannot be fully prepared to enter the world of legal employment.

The benefits of Pro Bono work to law students go far beyond the metaphorical moral pat on the back that is received by helping a client who may not otherwise be able to afford legal representation or advice which due to cuts in legal aid has become more prevalent in certain facets of the law. Pro Bono for a law student gives them the opportunity to understand what motivates a client and to manage their expectations for the outcome of their case as well as the more obvious experience of case management and professional conduct.

Academics have long discussed the ramifications of graduates that are technically sound in knowledge of the law itself and the procedural steps that accompany statute, but could not begin to understand the effects on a client of the application of said statute. For example, you may understand that an application can be made 
under Section 33 of the Family Law Act 1996 for an Occupation Order but until you have met the client who happens to be a victim of domestic violence, who fears for the safety of her children and understood how this application will affect this whole families life you cannot truly believe yourself to be educated in that area of law.

Speaking as a product of Northumbria University's Exempting Law Degree and having worked in their prestigious Student Law Office the benefits of Pro Bono are benefits that I have experienced personally. My resounding support for Pro Bono legal work therefore comes from experience. The prospect of meeting a live client for the first time does not fill me with dread as I postulate it may for some greenfingered trainees and I feel confident that I would be able to reassure a client who may be trusting me with what is ultimately a personal aspect of their life. For example, the creation of a will may be a frequent everyday task for a trainee, but for the client, that will is a document that will ultimately affect the lives of their most loved ones. The trainee will lose no sleep if 'Mrs Smith' decides to leave the sum of her assets to Battersea Dog's Home, but her spouse and five children will be vastly affected by this decision. The inclusion of Pro Bono client work in a degree ensures that legal graduates have some understanding of the personal effects of legal decisions.

Claire Eastwood 